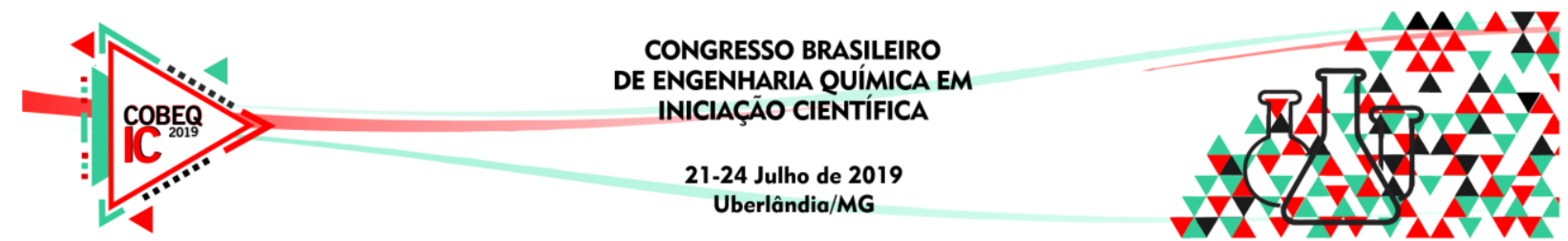

\title{
ANÁLISE DE FUNGOS E BACTÉRIAS LÁTICAS DO SORO FERMENTO UTILIZADO NA PRODUÇÃO DE QUEIJOS ARTESANAIS EM ARAXÁ, MINAS GERAIS
}

\author{
N.C. $\operatorname{COSTA}^{1}$, D.A. CORDEIRO ${ }^{1}$, C. A. BOARI ${ }^{2}$, M. A. DUMONT ${ }^{2}$, V.M. BENASSI ${ }^{1}$ \\ ${ }^{1}$ Universidade Federal dos Vales do Jequitinhonha e Mucuri campus JK, Instituto de Ciência \\ e Tecnologia \\ ${ }^{2}$ Universidade Federal dos Vales do Jequitinhonha e Mucuri campus JK, Departamento de \\ Zootecnia \\ E-mail para contato: nayanec.costa@hotmail.com
}

RESUMO - O modo artesanal de se fazer queijo nas fazendas mineiras se fez suficientemente expressivo da cultura da região fazendo com que fosse registrado como patrimônio imaterial brasileiro. "Segundo ORDOÑEZ (2005), o queijo pode ser descrito, de maneira mais simples, como um derivado lácteo obtido através da separação do soro após coagulação do leite". Esse trabalho teve como objetivo realizar um estudo microbiológico do soro fermento (pingo) utilizado na fabricação de queijos artesanais na cidade de Araxá, Minas Gerais. As amostras de pingo foram diluídas e inoculadas em distintos meios sólidos dependendo da análise microbiológica desejada, sendo esses o meio de cultura MRS para crescimento de bactérias, BDA enriquecido com ácido tartárico (10\%) para cultivo de fungos, e meio Yeast Extract Lactate Ágar para bactérias lácteas. As placas com os inóculos foram mantidas em estufa bacteriológica, durante 48 horas, à $25^{\circ} \mathrm{C}$ para crescimento, após este período, foi realizada a contagem de unidades formadoras de colônias para cada amostra. Das amostras analisadas, foram observadas duas amostras mais expressivas em relação à quantidade de UFC de bactérias láticas, quanto às colônias fúngicas, observou-se apenas uma amostra mais expressiva dentre as dezesseis analisadas, entretanto diante dos resultados obtidos, é possível notar um potencial expressivo tanto de contaminação, como de benefícios sensoriais para o produto final.

\section{INTRODUÇÃO}

"Segundo ORDOÑEZ (2005) queijo pode ser descrito, de maneira mais simples, como um derivado lácteo obtido através da separação do soro após coagulação do leite", sendo um produto de grande importância econômica e cultural em Minas Gerais, estado com abundante produção. O modo artesanal de se fazer queijo nas fazendas mineiras se fez suficientemente expressivo da cultura da região fazendo com que fosse registrado como patrimônio imaterial brasileiro.

A concepção do queijo minas artesanal baseia-se na elaboração deste derivado lácteo com certas especificações, segundo o Decreto no 44.864, de 01 de agosto de 2008 (Minas Gerais, 2008). O queijo deve ser produzido a partir do leite cru e integral, o processo de coagulação do leite deve ocorrer somente com a adição da quimosina do bezerro e do pingo, e a prensagem deve ocorrer de forma manual. 


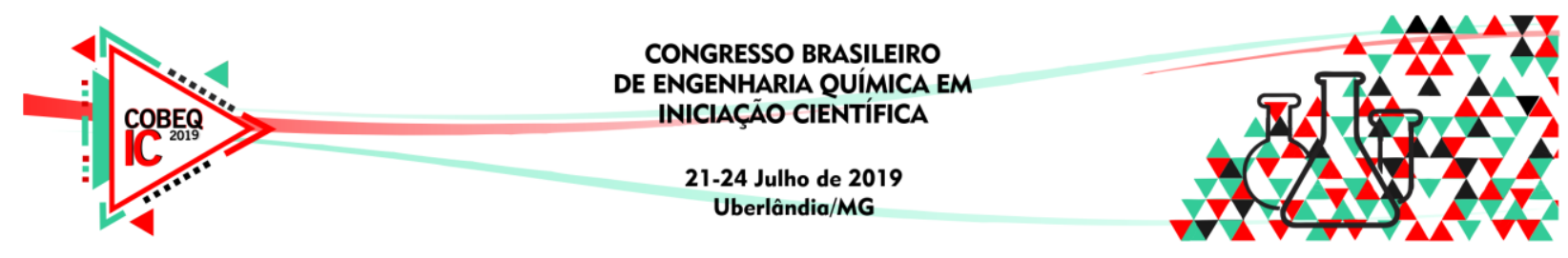

O pingo, soro fermento proveniente da batelada anterior, é adicionado ao leite na produção seguinte de forma a complementar o processo de fabricação com uma microbiota diversificada de bactérias láticas de maneira a proporcionar características organolépticas e sensoriais específicas aos queijos. O soro fermento endógeno é retirado após a etapa de salga, assim, é capaz de oferecer maior controle microbiológico e conferir sanidade ao produto durante os processos de produção e maturação.

"MAGALHÃES el al., (2009) fala que o sal presente no pingo é capaz de inibir a atividade fermentativa das bactérias láticas de forma a diminuir a produção de ácido lático necessária a coagulação do leite e propiciar mais substratos para micro-organismos contaminantes". Dessa forma, apesar da retirada do pingo após a etapa de salga oferecer maior controle microbiológico ao soro fermento, esse artifício se não for devidamente controlado é capaz de interferir na atividade das bactérias do ácido lático.

É possível, ainda, associar a maturação dos queijos com a atividade da composição microbiana do pingo, sendo que a microbiota do leite somente atua até a etapa do queijo fresco. Isso ocorre, pois, as bactérias presentes no leite são perdidas com o processo de maturação, sendo que as bactérias provenientes do pingo permanecem atuando no queijo. "Ocorre uma diminuição da população bacteriana presente no queijo, quando o produto está fresco este possui a população bacteriana semelhante ao leite cru, quando o processo de maturação se perfaz pode-se observar a presença somente de bactérias decorrentes do pingo adicionado o que diz CRUVINEL et al., (2016)".

As atenções quanto às questões higiênicas são ainda mais importantes ao trabalhar com o queijo artesanal devido à utilização do leite cru, uma vez que, o leite não passa por tratamentos térmicos, havendo a possibilidade de contaminação durante todo o manuseio e processamento. Assim, todos os procedimentos durante a fabricação devem ser realizados visando as boas práticas de manipulação e o aperfeiçoamento das condições higiênicosanitárias. Dessa forma, é possível promover a segurança alimentar do produto e impedir a contaminação, garantindo que nenhuma adversidade possa atrapalhar o processo produtivo.

Dessa forma, esse trabalho teve como objetivo quantificar específicos micro-organismos do pingo utilizado na fabricação de queijos minas artesanais de dezesseis produtores de Araxá, Minas Gerais, por influenciar diretamente no produto final.

\section{METODOLOGIA}

Utilizou-se diferentes metodologias de acordo com cada teste para análise microbiológica. Foram preparados os meios de cultura MRS (de MAN, ROGOSA and SHARPRE) para crescimento de bacterias láticas, BDA (Potato Dextrose Agar) enriquecido com ácido tartárico (10\%) para cultivo de fungos, os mesmos foram autoclavados à $120^{\circ} \mathrm{C}, 1,5 \mathrm{~atm}$, durante 30 minutos.

Após o preparo e esterilização dos meios de cultivos, os mesmos foram vertidos em placas de Petri esterilizadas, posteriormente seguiu-se o inóculo das amostras do pingo diluídas em 


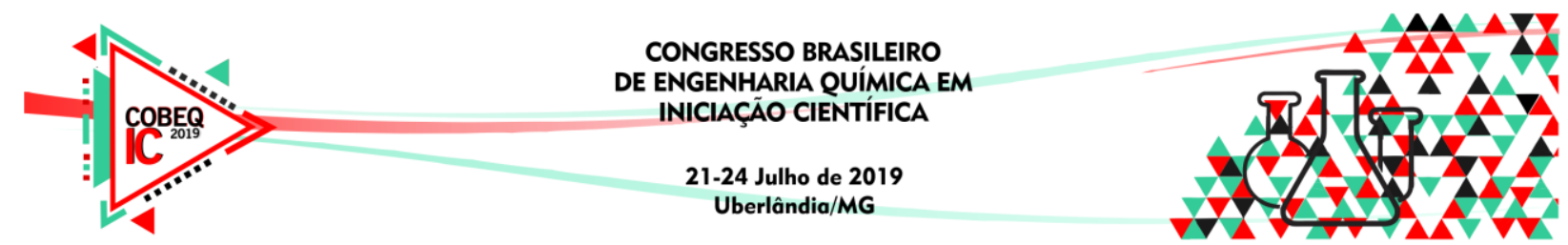

solução de $\mathrm{NaOH} 0,1 \mathrm{M}$, sendo as diluições de $10^{-2}$, $10^{-3}$ e $10^{-4}$, vale citar que, foram utilizadas duas placas por amostra, totalizando sessenta e quatro placas.

As placas com os inóculos foram mantidas em estufa bacteriológica, durante 48 horas, à $25^{\circ} \mathrm{C}$ para crescimento. Após este período, foi realizada a contagem de unidades formadoras de colônias para cada amostra.

\section{RESULTADOS}

Os resultados obtidos apresentaram grandes quantidades de unidades formadoras de colônias (UFC), o que mostrou potencial expressivo tanto de contaminação, como de benefícios sensoriais para o produto final.

Das amostras analisadas, foram observadas duas amostras mais expressivas em relação à quantidade de UFC de bactérias láticas, sendo as amostras identificadas como 10 e 7, que apresentaram valores de 3.035.000 UFC e 2.850.000 UFC, respectivamente, enquanto que a amostra identificada como 4 apresentou valores muito inferiores em relação às demais, de apenas 2.500 UFC (Figura 1).

Figura 1 - Unidades formadoras de colônias de bactérias láticas em soro fermento de dezesseis produtores de queijo artesanais da cidade de Araxá.

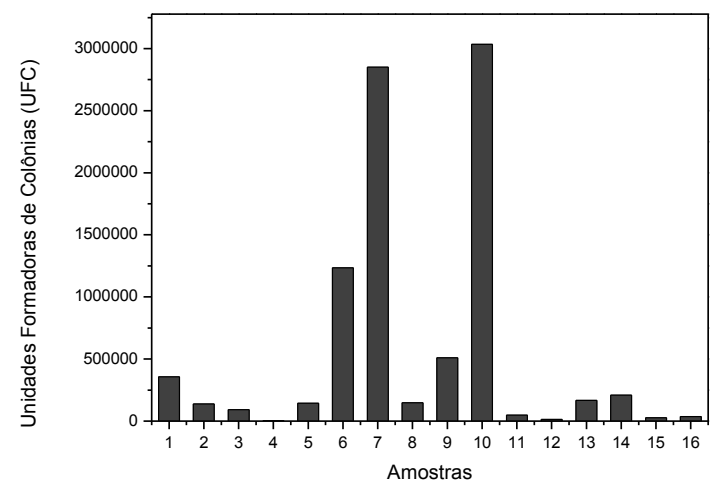

Quanto às colônias fúngicas, observou-se uma amostra mais expressiva dentre as dezesseis analisadas, sendo essa identificada como 7, que apresentou o valor de 725.000 UFC, enquanto que a menor contagem foi apresentada na amostra 2 com apenas 8.500 UFC (Figura 2).

Figura 2 - Unidades formadoras de colônias de fungos em soro fermento de dezesseis produtores de queijo artesanais da cidade de Araxá. 

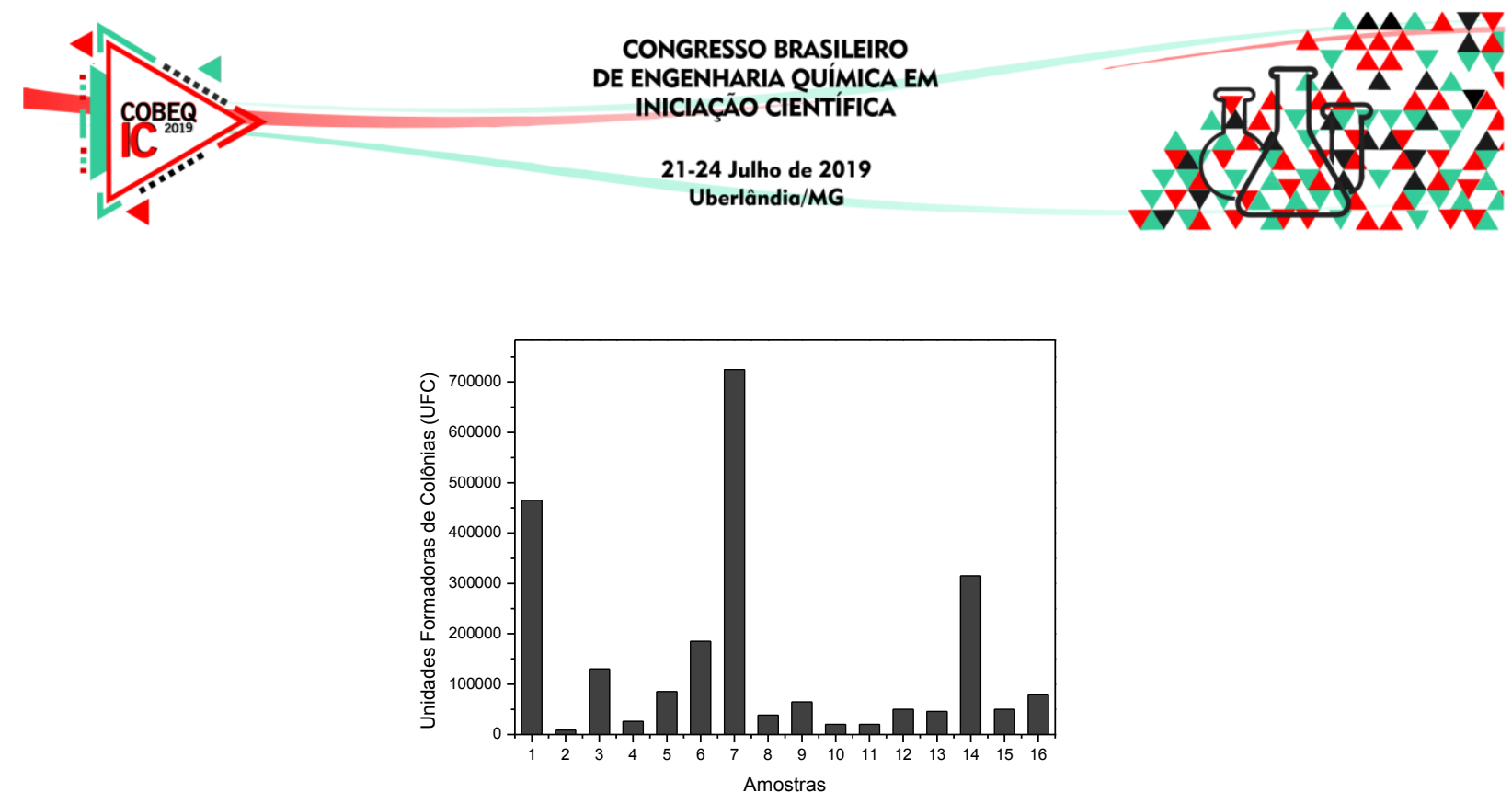

O modo de produção tradicional dos queijos artesanais faz com que as características físico-químicas, microbiológicas e sensórias do queijo sejam únicas em cada região de produção e em cada fazenda queijeira (MACHADO et al., 2004).

Ao analisar os valores obtidos com a contagem de bactérias do ácido lático presentes nas dezesseis amostras coletadas, pode-se observar que os pingos apresentaram, em sua maioria, valores semelhantes de bactérias láticas. As contagens obtidas se mostraram ligeiramente inferiores aos valores encontrados na literatura para pingos de queijos artesanais do estado de Minas Gerais, sendo capazes de oferecer a cultura lática em quantidades expressivas (RAFAEL, 2017).

As variações entre as contagens de bactérias láticas se justificam ao se levar em conta que, apesar de ter se tornado um costume na fabricação do queijo artesanal, não se sabe ao certo a composição microbiana do soro fermento de cada produtor ou remessa de produção, sendo que o pingo é composto, principalmente, de bactérias do ácido lático (CRUVINEL et al., 2016).

Os valores obtidos para a contagem de fungos apresentaram maiores variações. No entanto, as contagens mais numerosas de fungos, entre as amostras analisadas, apresentaram ordem semelhante aos valores encontrados na literatura.

Os fungos, leveduras, e os micro-organismos deteriorantes estão mais relacionados à vida útil do produto, à aparência, e aos riscos à saúde do consumidor. Assim como, a contaminação dos pingos observados está relacionada à má higienização do ambiente de produção, haja visto que, a contaminação por fungos e leveduras tem como o principal meio o ar. No entanto, não há legislação atualmente que possa oferecer os parâmetros necessários ao controle desses micro-organismos na produção do queijo, sobretudo na composição dos pingos utilizados (SOARES, 2014).

A não padronização desse produto impossibilita que os queijos artesanais tenham parâmetros de qualidade totalmente comuns entre si, haja visto que o modo artesanal de fabricação propícia que cada fazenda queijeira possua suas especificidades. A conservação da microbiota natural do leite requer maior cuidado durante o todo processo produtivo, desde a ordenha até o produto final embalado, com o intuito de prevenir possíveis contaminações que 


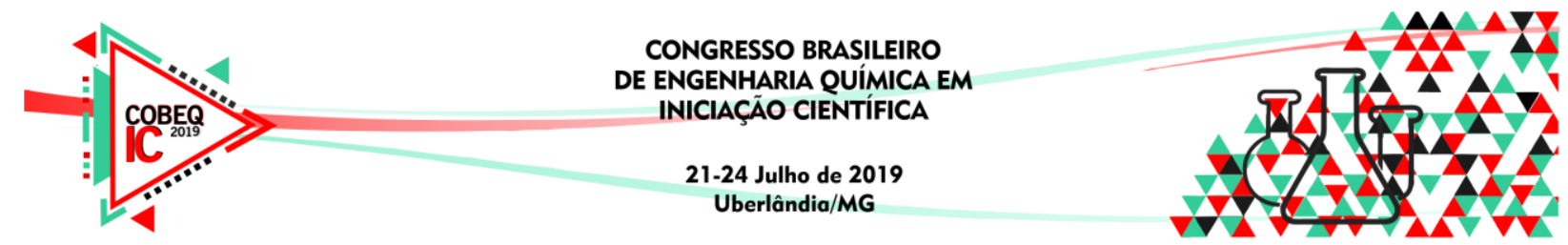

possam resultar em problemas tecnológicos. A população microbiana do pingo reflete como as condições de higiene dos processos da batelada anterior foram ministrados, dando continuidade à produção. Dessa forma, a produção de queijos artesanais requer condições higiênico - sanitárias adequadas durantes todas as etapas de produção, uma vez que a contaminação de um lote pode ser repassada a outros lotes por meio do pingo, e dessa maneira, ser capaz de proporcionar maior qualidade e segurança alimentar sem que as tradições que envolvam sua produção sejam corrompidas, perpetuando a utilização do pingo (MACHADO et al., 2004)..

\section{REFERÊNCIAS}

CRUVINEL, L. A.; MELO, S. N.; Gustavo Augusto Lacorte. Caracterização das comunidades bacterianas do processo de produção do queijo Canastra por meio de análise metanogênica. In: II Seminário Estudantes de Pós-graduação - II SEP, 2016, Bambuí. Anais do II Seminário dos Estudantes de Pós-graduação - II SEP, 2016.

MACHADO, E. C. et al. Características físico-químicas e sensoriais do queijo Minas artesanal produzido na região do Serro, Minas Gerais. Ciência e Tecnologia de Alimentos, v. 24, p. 516-521, 2004.

MAGALHÃES, F. A. R. et al. Avaliação da viabilidade técnica do emprego de resina para tratamento da casca de queijos artesanais da Canastra. Revista do Instituto de Laticínios Cândido Tostes, v. 64, n. 370, p. 39-43, 2009.

ORDÓÑEZ, J. Tecnologia de alimentos. Volume 2. Alimentos de origem animal - 1 a . Ed., Ed. Artmed. 2005. 279p.

SOARES, D. B. Caracterização físico-química e microbiológica do queijo minas artesanal da região de Uberlândia-MG. 2014, 124f. Dissertação (Mestrado em Ciências Veterinárias). Universidade Federal de Uberlândia, Uberlândia. 